Dept. of Parasitology,

Fac. Vet. Med., Beni-Suef Univ.

\title{
PREVALENCE OF CYSTICERCUS BOVIS IN CATTLE AND BUFFALOES IN BENI-SUEF GOVERNORATE WITH SPECIAL REFERENCE FOR DETERMINATION OF SPECIFIC EPITOPE BY WESTERN BLOT
}

(With 3 Tables, One Figure and One Plate)

By

\author{
KH.M. EL-DAKHLY and H.S. LOTFI* \\ * Animal Health Research Institute, Beni-Suef
}

(Received at 4/6/2007)

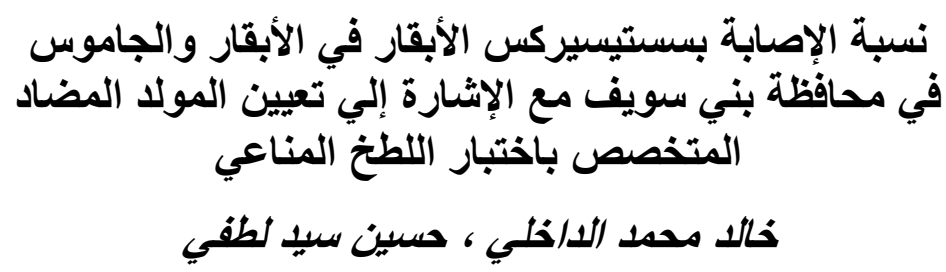

أجريت هذه الدراسة لاستييان نسبة إصابة الأبقار و الجاموس بيرقات سستيسيركس الأبقار في

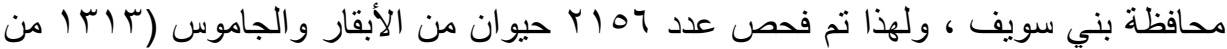

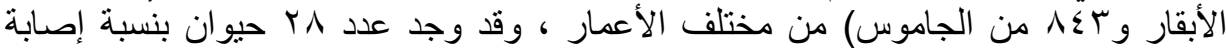

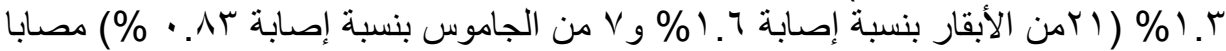

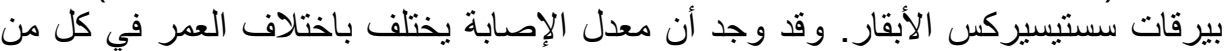

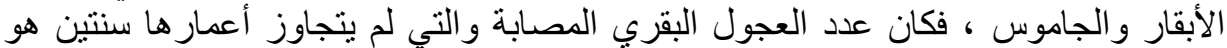

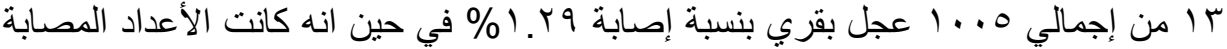

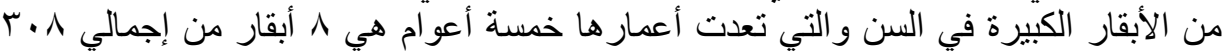

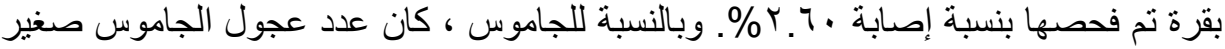

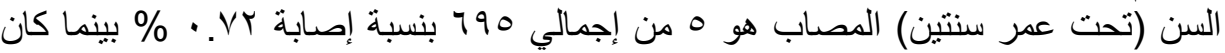

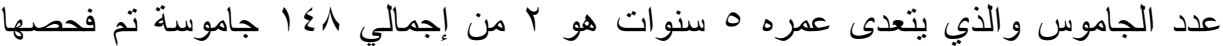

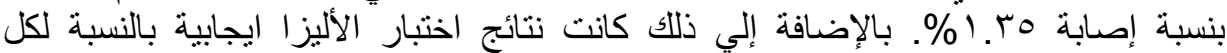

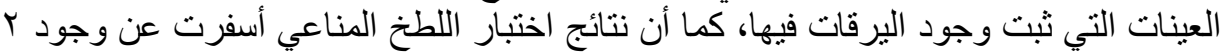

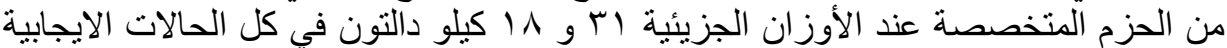

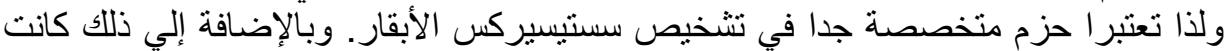

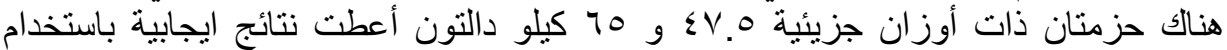

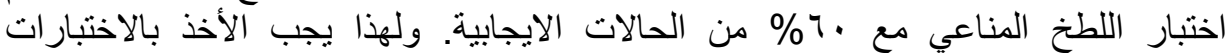

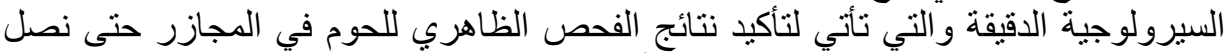

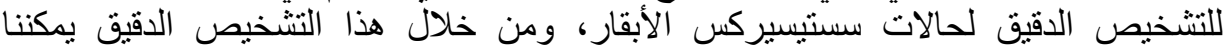
السبطرة بشكل مناسب علي المرض. 


\section{SUMMARY}

This study was performed to investigate the prevalence of Cysticercus bovis infection in both cattle and buffaloes in Beni-Suef Governorate. For this purpose, a total number of 2156 cattle and buffaloes (1313 cattle and 843 buffaloes) of different ages were examined in Beni-Suef abattoir. Among those, 28 animals (cattle and buffaloes) were infected with $C$. bovis with a percentage of $1.3 \%$. Among cattle, 21 animals were infected with a percentage of $1.6 \%$, while 7 buffaloes of different ages were infected with a percentage of $0.83 \%$. Moreover, we found that infection rate was affected by aging i.e. among 1005 cattle calves of upto 2 years, only 13 were positive for cysticercosis by meat inspection with a percentage of $1.29 \%$, while among 308 old-aged cattle of at least 5 years, 8 cows were infected with a percentage of $2.6 \%$. On the other hand, examination of 695 buffalo calves of upto 2 years revealed 5 calves infected with $C$. bovis with a percentage of $0.72 \%$, while old-aged buffaloes of more than 5 years showed 2 affected animals with a percentage of $1.35 \%$. Besides, application of ELISA revealed positive results for all cases showed $C$. bovis by meat inspection. Moreover, results of Western blot showed 2 bands of molecular weights $31 \mathrm{kDa}$ and $18 \mathrm{kDa}$ respectively found in all positive cases for cysticercosis, so they are considered as highly diagnostic bands for diagnosis of bovine cysticercosis. Also, 2 bands of molecular weights $47.5 \mathrm{kDa}$ and $65 \mathrm{kDa}$ were found in $60 \%$ of positive cases. Therefore, serological tools should be used parallel with routine meat inspection in abattoirs in order to obtain an appropriate data on bovine cysticercosis and so we can reach the proper means of control.

Key words: C. bovis, cattle, buffaloes, ELISA.

\section{INTRODUCTION}

Cattle and buffaloes are considered a major element of our Egyptian economy. They represent a multi-source for human being nutrients, including meat, milk and hides. Their proteins are considered the most important category of animal protein used for human consumption.

Therefore, these multiple resources must be away from all diseases that subside their quality and quantity. Among these diseases, parasitic ones are of great importance in several districts especially 
tropical and subtropical countries (Thornoton and Gracey, 1974 and Sahar, 2005).

Among parasites, the metacestode Cysticercus bovis, the larval stage of Taenia saginata, particularly widely spread usually in cattle and buffaloes. So, taeniasis is common in districts in which people are adapted to bad feeding habits such as eating raw, insufficiently cooked or smoked meat, or where poor sanitary conditions favour the dispersal of stools from infected persons in fields together with improper meat inspection in slaughter houses (Thornoton and Gracey, 1981).

Cysticercosis are widely spread throughout the world and responsible for considerable economic losses, in addition to its public health importance. Therefore, control of the disease should represent both treatment of persons infected with adult worms and careful routine meat inspection in abattoirs for detection of Cysticercus bovis in muscles (Darweish, 1981).

Obviously, routine meat inspection in abattoirs do not absolutely confirm the presence of bovine cysticercosis (Thieulin et al., 1963 and Walther and Koske, 1979) due to irregular distribution of Cysticerci in different locations of muscles in the carcass, so the need of more advanced techniques including serological tests such as ELISA (Hughes et al., 1993; Wanzala et al., 2002 and Omnia, 2004) and immunoblot (Kamanga-Sollo et al., 1987) must be required to confirm bovine cysticercosis.

The aim of the present work represent prevailing the incidence of Cycticercus bovis infection in cattle and buffaloes in Beni-Suef Governorate in relation to different ages as well as application of some serological tests as ELISA and Western blot to confirm diagnosis of bovine cysticercosis.

\section{MATERIALS and METHODS}

\section{Collection of serum samples:}

A total number of 2156 cattle and buffaloes were subjected to post-mortem examination in Beni-Suef abattoir to detect the presence of Cycticercus bovis in different muscles including heart, tongue and masseters. Among them, 1313 were cattle (1005 cattle calves of up to 2 years and 308 cows of more than 5 years) and 843 were buffaloes (695 buffalo calves of up to 2 years and 148 old-aged buffaloes of more than 5 years). 
Blood samples were obtained in clean, dry and labelled test tubes from all slaughtered animals, then only serum samples of cysticercipositive animals (40) as well as number of apparently negative ones (40) were preserved for serological studies.

For each blood sample, serum was collected, labeled and stored at $-20^{\circ} \mathrm{C}$.

\section{Collection of Cycticercus bovis cysts:}

Cysts collected were carefully removed from the surrounding tissues without injuring the cyst wall, then washed thoroughly with dist. water and rewashed in PBS ( $\mathrm{pH} 7.2$ ) and kept at $-20^{\circ} \mathrm{C}$ till use. Serum samples and suspensions of cysts were transferred to the laboratory for investigation.

\section{Serological study:}

\section{a- Preparation of Cycticercus bovis antigen:}

Processing of Cycticercus bovis antigen was done according to Van Kerchoven et al. (1998) as follows:

Cysts were washed 3 times in Phosphate Buffer Saline (PBS) pH. 7.2 , then homogenized for 10 minutes, followed by sonication on ice for 5 minutes. Samples were examined for disruption of the contact portions of the cysts. The sonicated materials were centrifuged at $14000 \mathrm{rpm}$ for 30 minutes at $4{ }^{\circ} \mathrm{C}$, then the supernatant containing antigenic materials was collected. Protein contents of the supernatant were determined according to Lowry et al. (1951), then stored in sterile tubes at $-20^{\circ} \mathrm{C}$.

\section{b- Application of ELISA:}

The assay was performed according to Iacona et al. (1980) as follows:

ELISA plate, of 96-flat bottom wells, were coated with $100 \mu 1$ of $40 \mu \mathrm{g} \mathrm{C}$. bovis antigen in carbonate buffer ( $\mathrm{pH}$ 9.6) separately. The plates were incubated overnight at room temperature. Following blocking with $0.1 \%$ Bovine Serum Albumin (BSA) in coating buffer, $100 \mu \mathrm{l}$ of buffalo sera diluted at 1: 100 in PBS was added for 2 hours at $37^{\circ} \mathrm{C}$ in shaking water bath. After washing, the plates 5 times with PBS containing $0.05 \%$ Tween-20, $100 \mu \mathrm{l}$ of alkaline phosphatase labelled anti-bovine $\mathrm{IgG}$ diluted at $37^{\circ} \mathrm{C}$ in shaking water bath. The chromogen p-nitrophenyl phosphate, at a concentration of $1 \mathrm{mg} / \mathrm{ml}$ substrate buffer was added and the absorbance of the colored reaction was read within 30 minutes at $405 \mathrm{~nm}$ using a titerek multiskan ELISA reader. The positively threshold value was determined as double fold the mean optical density of the negative sera. 


\section{c- Immunoblotting:}

After electrophoresis, protein bands of $C$. bovis were transferred to nitrocellulose sheet using a modified technique according to Towbin et al. (1979) as follows:

A sheet of nitrocellulose $(0.45 \mu \mathrm{m}$ pore size $)$ was briefly wetted with a transfer buffer $(25 \mathrm{mM}$ tris base; $192 \mathrm{mM}$ glycine $20 \%$ vol./vol. and methanol at $\mathrm{pH}, 8.31$ ) and laid on a scouring pad (Scotch-Brite) which was supported by a stiff plastic grid. The gel wanted to be blotted was put on the nitrocellulose sheet and care must be taken to discard all air bubbles in between them. Gel was evenly pressed against nitrocellulose sheet, then put on an electrophoretic chamber containing a transfer buffer with the nitrocellulose sheet facing the anode. The electrophoretic chamber was put at $4{ }^{\circ} \mathrm{C}$ and a voltage of $100 \mathrm{v}$ was applied for one hour.

Nitrocellulose sheets were soaked in blocking buffer (PBS containing 3\% BSA) for 2 hours, then washed by buffer (PBS containing $0.3 \%$ Tween) for 5 minutes, followed by exposure to sera with diluted antibodies (1:100 diluted in PBS) for one hour. Washing 2-3 times with 5 minutes interval, then exposed to alkaline phosphatase labeled antibody (1:3000 diluted in PBS) for one hour. Washing 2-3 times with 5 minutes interval, and finally nitrocellulose sheet was exposed to substrate (BCIP/NPT) for 10 minutes then thoroughly rinsed with distilled water to stop the reaction. The reaction was read by Gel proanalyzer.

\section{RESULTS}

\section{Concerning incidence of $\boldsymbol{C}$. bovis infection in cattle and buffaloes:}

The present study revealed that out of 7692 slaughtered cattle and buffaloes, in slaughter house of Beni-Suef Governorate, 40 animals were infected with $C$. bovis with a percentage of $0.52 \%$. Among those, 6849 examined cattle showed 22 ones positive for cysticercosis with a percentage of $0.32 \%$, and a number of 18 buffaloes were infected with C. bovis among 843 examined with a percentage of $2.14 \%$.

Moreover, aging of both cattle and buffaloes affected the incidence of $C$. bovis infection in the examined animals. All animals were classified, according to aging, into 2 categories; the first one includes calves of upto 2 years and the second includes those exceed 5 years old. In the examined cattle, a number of 6629 belonged to the first category and they showed 16 infected calves with a percentage of 
$0.24 \%$, and among 220 old-aged cows, 6 only were infected with a percentage of $2.73 \%$. Besides, among 695 buffalo calves, 6 calves were positive for cysticercosis with a percentage of $0.86 \%$, while among 148 old-aged buffaloes, 12 animals were infected with a percentage of infection $8.11 \%$.

\section{Evaluation of Cycticercus bovis infection in cattle and buffaloes by using ELISA:}

ELISA was performed on sera of cattle and buffaloes naturally infected with $C$. bovis as well as apparently normal non-infected ones of different ages. The cut off value was 0.300 (the positively threshold value considered as double fold of mean negative sera).

Results of ELISA applied on naturally infected cattle and buffaloes revealed that, all cases (40) gave positive results when examined against $C$. bovis antigen by ELISA (mean O. D is 0.435 ) with a sensitivity percentage of $100 \%$. On the other hand, another 40 apparently free from $C$. bovis infection, all gave negative results (mean O.D is 0.146) when tested against the same antigen.

\section{Evaluation of Cycticercus bovis infection in cattle and buffaloes by using Western blot:}

In our study, $C$. bovis antigen was evaluated with its corresponding antisera, to determine the specific epitope (s) applied for diagnosis of bovine cysticercosis by using Western blot (Plate 1). The results cleared that 2 bands were detected in all positive cases of bovine cysticercosis. These 2 bands were of molecular weights $31 \mathrm{kDa}$ and 18 $\mathrm{kDa}$ respectively. In addition, another 2 bands of molecular weights 47.5 $\mathrm{kDa}$ and $65 \mathrm{kDa}$ were obvious in $60 \%$ of the detected positive cases. These data revealed that bands of molecular weights $31 \mathrm{kDa}$ and $18 \mathrm{kDa}$ were highly specific and so they are considered highly diagnostic for bovine cycticercosis.

Table 1: Incidence of Cycticercus bovis infection among cattle and buffaloes in Beni-Suef Governorate.

\begin{tabular}{|l|c|c|c|}
\hline \multirow{2}{*}{ Animal species } & \multirow{2}{*}{$\begin{array}{c}\text { No. of examined } \\
\text { animals }\end{array}$} & \multicolumn{2}{|c|}{ Infected animals } \\
\cline { 3 - 4 } & 1313 & 21 & $\%$ \\
\hline Cattle & 843 & 7 & 1.6 \\
\hline Buffaloes & 2156 & 28 & 0.83 \\
\hline Total & & 1.3 \\
\hline
\end{tabular}


Table 2: Incidence of Cycticercus bovis infection among cattle and buffaloes in relation to age.

\begin{tabular}{|c|c|c|c|c|}
\hline \multirow{2}{*}{\multicolumn{2}{|c|}{ Animal species }} & \multirow{3}{*}{$\begin{array}{c}\begin{array}{c}\text { No. of examined } \\
\text { animals }\end{array} \\
1005\end{array}$} & \multicolumn{2}{|c|}{ Infected animals } \\
\hline & & & \multirow{2}{*}{$\frac{\text { No. }}{13}$} & \multirow{2}{*}{$\begin{array}{c}\% \\
1.29\end{array}$} \\
\hline \multirow{2}{*}{ Uే } & $\begin{array}{l}\text { Cattle calves } \\
\text { (upto } 2 \text { years) }\end{array}$ & & & \\
\hline & $\begin{array}{l}\text { Old-aged cattle } \\
\text { (more than } 5 \text { years) }\end{array}$ & 308 & 8 & 2.60 \\
\hline \multirow{2}{*}{ 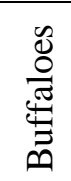 } & $\begin{array}{l}\text { Buffalo calves } \\
\text { (upto } 2 \text { years) }\end{array}$ & 695 & 5 & 0.72 \\
\hline & $\begin{array}{l}\text { Old-aged buffaloes } \\
\text { (more than } 5 \text { years) }\end{array}$ & 148 & 2 & 1.35 \\
\hline
\end{tabular}

Table 3: Evaluation of Cysticercus bovis infection in cattle and buffaloes by using ELISA.

\begin{tabular}{|l|c|c|c|}
\hline No. of tested animals & Minimal reading & Maximal reading & Mean \\
\hline 28 positive animals & 0.352 & 0.603 & 0.477 \\
\hline $\begin{array}{l}52 \text { apparently negative } \\
\text { animals }\end{array}$ & 0.116 & 0.191 & 0.153 \\
\hline
\end{tabular}

Fig. 1: Heart of cattle showing Cysticercus bovis 


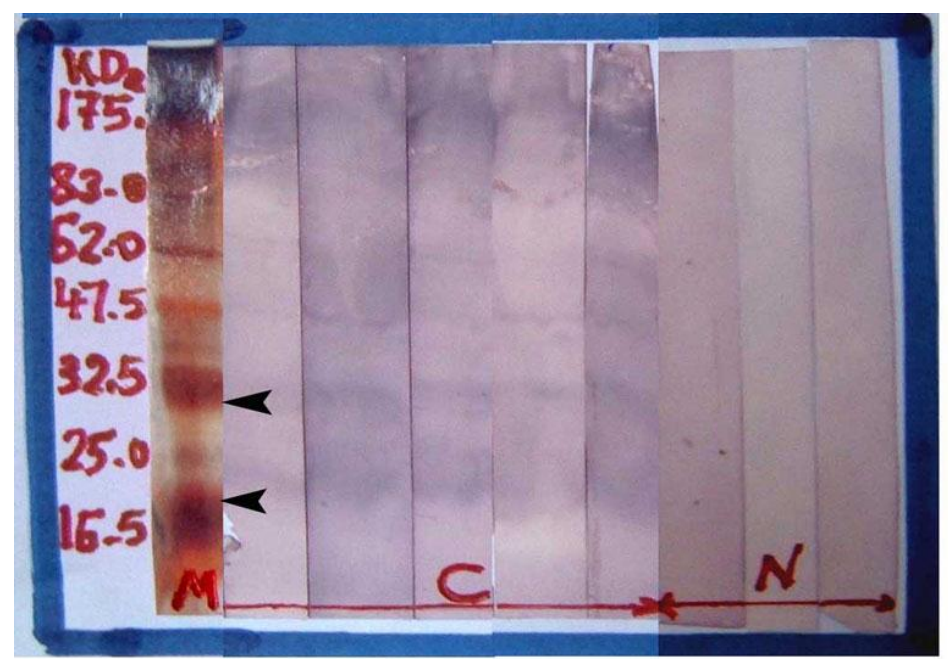

Plate 1: Results of immunoblot against Cysticercus bovis showing bands of molecular weights $18 \mathrm{kDa}$ and $31 \mathrm{KDa}$ that were specific for cysticercosis

\section{DISCUSSION}

The metacestode Cycticercus bovis found in several muscles including heart, tongue and masseters in both cattle and buffaloes in different localities of the world.

Incidence of $C$. bovis infection among cattle may be influenced by means of stock husbandry and management as well as by standard of hygiene. Also, assistants of the farm and herdsmen and their living habits that allow them to stay close to the animals in addition to their low levels of sanitation associated with a high rate of Taenia saginata infection, all may expose the stock to a high risk of infection with C. bovis.

In the present study, infection rates among cattle and buffaloes were $0.32 \%$ and $2.14 \%$ respectively. These results agreed with those obtained by Lotfi et al. (1976) in Iraq, who found an infection rate $0.42 \%$ among cattle; El-Saieh (1982) in Egypt who found infection rate $2.65 \%$ among buffaloes and Maha (1994) who also revealed infection rate $3.95 \%$ among buffaloes. On the contrary, our results disagreed with those obtained by Bundaza et al. (1988) in Canada (37\%); Okafor (1988) in Nigeria (26.14\% among) and Maha (1994) in Egypt (7.8\%). Moreover, among buffaloes our results disagreed with those obtained by Awad (1981) in Egypt (0.11 \%); Haridy et al. (1999) in Egypt (0.14 \%) 
and Krishnan and Ranganathan (1972) in India (0.72\%). This variation in infection rates among cattle and buffaloes might be related to the environmental and sanitary conditions of the slaughtered animals.

As more specified diagnostic tool for bovine cysticercosis, some immunological procedures such as ELISA and Western blot should be used (Van Weeman and Schuurs, 1971) for detection of parasitic antigens.

In the present study, sensitivity of ELISA to C. bovis antigen was $100 \%$ among the positive cases. These results agreed with those obtained by Kamanga-Sollo et al. (1991); Draelents et al. (1995) and Van Kerchoven et al. (1998).

Regarding to Western blot, 2 bands of molecular weights $31 \mathrm{kDa}$ and $18 \mathrm{kDa}$ were obtained that gave positive results with all naturally infected cases. These data go parallel with those obtained by Bogh et al. (1995) who could detect specific band of molecular weights ranging from $10-18 \mathrm{kDa}$ used for diagnosis of bovine cysticercosis. On the other hand, Haynnga and Sumner (1991) detected specific band less than $12 \mathrm{kDa}$ for ovine cycticercosis. This variation in specific bands might be referred to host variation as well as method of processing and preparation of parasitic antigens.

Moreover, our study revealed bands of $47.5 \mathrm{kDa}$ and $65 \mathrm{kDa}$ gave $60 \%$ specificity with bovine cycticercosis.

From the previous data, we can conclud that the application of Western blot with specification of two bands (18 kDa and $31 \mathrm{kDa})$ may be a tool to confirm diagnosis of bovine cysticercosis and may be applied for further studies as a role of vaccination.

\section{REFERENCES}

Awad, Y.L. (1981): A statistical approach to emergency slaughtered animals in Egypt. Agric. Res. Rev., 59 (7): 223-236.

Bogh, H.O.; Lind, P.; Sonderby, B.V.; Kyvsgaard, N.C.; Maeda, G.E.; Henriksen, S.A. and Nansen, D. (1995): Immunodiagnosis of Taenia saginata in cattle using hydrophobic antigens from Taenia hydatigena metacestode cyst fluid. Appl. Parasitol., 36 (3): 226-238.

Bundza, A.; Finely, G.G. and Easton, K.L. (1988): An outbreak of cysticercosis in feedlot cattle. Can. Vet. J., 29 (12): 933-996.

Darweish, A.H. (1980): Investigation on detection of Cysticerci among cattle. Ph. D. Thesis, Fac. Vet. Med., Cairo Univ. 
Draeleants, E.; Hofkens, E.; Harding, E.; Brandt, J. and Geerts, S. (1995): Development of a dot-enzyme immunoassay for the detection of circulating antigen in cattle infected with Taenia saginata cycticerci. Res. Vet. Sci., 58 (1): 99-100.

El-Saieh, A.F. (1982): Incidence of bovine cysticercosis in slaughtered animals in upper Egypt. M.V.Sc. Thesis, Fac. Vet. Med. Assiut Univ.

Haridy, F.M.; Ibrahim, B.B.; Morsy, T.A. and Ramadan, N.I. (1999): Human taeniasis and cysticercosis in slaughtered cattle, buffaloes and pigs in Egypt. J. Egypt Soc. Parasitol., 29 (2): 375-94.

Hayunga, E.G. and Sumner, M.P. (1991): Isolation and purification of a diagnostic antigen for bovine cysticercosis by hydrophobic chromatography. Vet. Immunol. Immunopathol., 28 (1): 57-65.

Hughes, G.; Hoque, M.; Tewes, M.S.; Wrights, S.H. and Harrison, L. (1993): Seroepidemiological study of Taenia saginata cycticercosis in Swaziland. Res. Vet. Sci., 55 (3): 287-291.

Iacona, A.; Pini, C. and Vicari, G. (1980): Enzyme-Linked ImmnunoSorbent Assay (ELISA) in the serodiagnosis of hydatid disease. Am. J. Trop. Med. Hyg., 29 (1): 95-102.

Kamanga-Sollo, E.L.; Lindqvist, K.J. and Musoke, A.J. (1991): Identification of antigens for use in immunodiagnosis of Taenia saginata cysticercosis. Res. Vet. Sci., 50 (2): 162-169.

Kamanga-Sollo, E.L.; Rhoads, M.L. and Murrell, K.D. (1987): Evaluation of antigenic fraction of Taenia hydatigena metacestode cyst fluid for immunodiagnosis of bovine cysticercosis. Am. J. Vet. Res., 48 (8): 1206-1210.

Krishanan, K.R. and Ranganathan, M. (1972): A survey of the incidence of Cysticercus bovis in bovines slaughtered at the Madras corporation slaughter house. Indian Vet. J., 49(12): 1182-1184.

Lotfi, A.Y.; Al-Murrant, W.Y. and Al-Ashmawtn, A.M. (1976): Incidence of bovine cysticercosis in Iraq and its impact on meat-born helminthic. Iraq Med. J., (2-3): 24-56.

Lowry, O.H.; Rosebrough, N.J.; Farr, A.L. and Randall, R.J. (1951): Protein measurements with folin phenol reagent. J. Biol. Chem., 193: 265-275.

Maha, E.B. (1994): Serological studies on cysticercosis and hydatidosis in cattle and buffaloes. M.V.Sc. Thesis, Fac. Vet. Med. Cairo Univ. 
Okafor, F.C. (1988): Epizootiology of Cysticercus bovis in Ino State, Nigeria. Angewandte parasitologie, 29 (1): 25-30.

Omnia, M.K.; Olfat, A.M.; Sanna, K.A. and Mousa, W.M. (2004): Purification and characterization of 3 larval taeniid antigens by gel filtration. Giza Vet. Med. J., 52 (4): 449-456.

Sahar, Z.A. (2005): Studies on metacestodes of sheep with reference to serodiagnosis of Coenuris cerebralis. Ph. D. Thesis, Fac. Vet. Med., Cairo Univ.

Thieulin, G.; Pantaleen, J. and Rosset, R. (1963): La cysticercose bovine rechercé d'une prophylaxia rationella. Int. Vet. Congr. $17^{\text {th }}$ Hannover., 11: 881-884.

Thornoton, H. and Gracey, J.F. (1974): Meat Hygiene, Textbook. $6^{\text {th }}$ ed, The English Language Book Society \& Bailliere Tindall, London.

Thornoton, H. and Gracey, J.F. (1981): Thornton's Meat Hygiene: parasitic diseases, Cycticercus bovis and Sarcosporidia. The English Language Book Society \& Bailliere Tindall $7^{\text {th }}$ ed.

Towbin, H.; Stacheline, T. and Gorden, J. (1979): Electrophoretic transfer of protein from polyacrylamide gel to nitrocellulose sheets: procedure and some applications. Protocols of National Academy of Science, 76: 4350-4354.

Van Kerckoven, I.; Vansteenkiste, W.; Claes, M.; Geerts, S. and Brant, $J$. (1998): Improved detection of circulating antigen in cattle infected with Taenia saginata metacestodes. Vet. Parasitol., 76(4): 269-274.

Van Weemen, B.K. and Schuurus, A.H. (1971): Immuno-assay using antigen-enzyme conjugates. FEBS letters, 15: 232-236.

Walther, M. and Koske, J.K. (1979): Efficacy of Praziquentel against Taenia saginata Cysticercosis in naturally infected calves. Tropenmedizin and parasitologie, 30 (3): 401-403.

Wanzala, W.; Oryango-Abuje, J.A.; Kangethe, E.K.; Ochanda, H. and Harrison, L.J. (2002): Serodiagnosis of bovine cysticercosis by detecting live Taenia saginata cysts using a monoclonal antibody-based antigen ELISA. J. S. Afr. Vet. Assoc., 73 (4): 201-206. 
Assiut Vet. Med. J. Vol. 53 No. 114 July 2007 
Assiut Vet. Med. J. Vol. 53 No. 114 July 2007

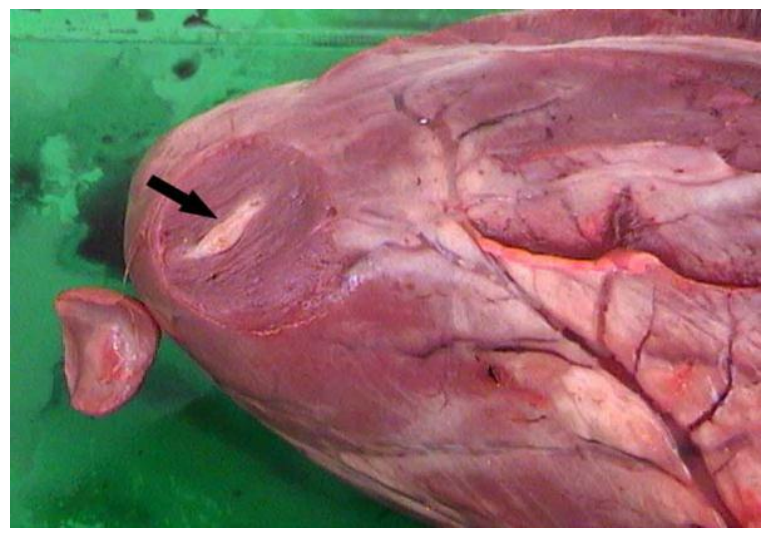

